\title{
A Multisensor Analysis of the Life Cycle of Bow Echo over Indian Region
}

\author{
Devajyoti Dutta, ${ }^{1,2}$ Diganta Kumar Sarma, ${ }^{3}$ and Sanjay Sharma ${ }^{1}$ \\ ${ }^{1}$ Department of Physics, Kohima Science College, Jotsoma, Kohima, Nagaland 797002, India \\ ${ }^{2}$ NCMRWF, A-50, Sector 62, Noida 201307, India \\ ${ }^{3}$ B. Borooah College, Guwahati 781007, India
}

Correspondence should be addressed to Devajyoti Dutta; devankaster@gmail.com

Received 21 May 2014; Revised 11 August 2014; Accepted 31 August 2014; Published 29 October 2014

Academic Editor: Bodo Ahrens

Copyright (C) 2014 Devajyoti Dutta et al. This is an open access article distributed under the Creative Commons Attribution License, which permits unrestricted use, distribution, and reproduction in any medium, provided the original work is properly cited.

\begin{abstract}
This study deals with the life cycle of bow echo events on October 24 and 26-27, 2006, from Doppler weather radar (DWR) observations supported by Radiosonde and National Centers for Environmental Prediction (NCEP). The cell bow echo (CBE) on October 24 evolved from two small isolated cells with radar reflectivity $\geq 40 \mathrm{dBZ}$. The vertical structure consists of one single mature cell with $20 \mathrm{dBZ}$ echoes reaching up to $10 \mathrm{~km}$ while $40 \mathrm{dBZ}$ echoes extended uniformly from ground to $\sim 5 \mathrm{~km}$ height. The radial velocity shows a high value $>-15 \mathrm{~m} / \mathrm{s}$ towards the radar at the upper height (about 6 to $11 \mathrm{~km}$ ); the lower height is predominant with velocity away from the radar (about 5 to $15 \mathrm{~m} / \mathrm{s}$ ). The squall line bow echo on October 26 and 27 has its origin over ocean and moved towards the radar site and decayed thereafter. The radar reflectivity pattern for this squall line showed it to be a trailing stratiform type squall line with length of $\sim 200 \mathrm{~km}$. The echo top height was more than $12 \mathrm{~km}$ in height. Strong inflow cases were observed from both radiosonde and radar.
\end{abstract}

\section{Introduction}

The life cycle of mesoscale convective systems (MCSs) can be studied with the help of on-board IR and microwave sensors as well as ground based Doppler weather radar (DWR) [1]. Though the geostationary IR data is very useful for the study of evolution of MCSs because of its large areal coverage, it can give only the cloud top information but unable to give details inside of the system. On the other hand, DWR can give much better information of the MCS but their coverage is limited, where the reliable observation $>200 \mathrm{~km}$ is restricted due to the refraction of the transmitted signal. The passive microwave radiometer cannot be used for the study of the evolution of MCSs as these are carried by polar satellite with low repetition. A multisensor approach is useful approach to study the multifaceted characteristics of MCSs. Till date many of the studies of MCSs are performed with the help of both active and passive sensors: evolution (e.g., [2-6]), size and structure $[7,8]$, and reflectivity structures (e.g., [9-12]).
The severe weather events are mostly associated with the organized MCSs such as bow echoes and squall lines. Bow echoes were named and described in detail by Fujita [13]. A bow echo is defined as a nontransient bow or crescent shaped radar signature with a high reflectivity gradient on the convex edge. Most of the time, they are associated with severe weather. According to Fujita [13] the bow echo commonly evolves from either a single convective cell or a line of cells. Klimowsky et al. $[14,15]$ studied the early evolution of bow echoes from radar observations. They observed three initial modes of formation of bow echoes: (i) weakly organized cells, (ii) squall line, and (iii) super cells. Form 273 bow echo events they found that about 45\% (122 cases) of the bow echoes evolved from weakly organized cells while $40 \%$ evolved from squall line. Only $15 \%$ of the bow echoes were supercell initiated. The cell bow echo (CBE) category proposed by Lee et al. $1992[16,17]$ occurs on very small scales $(\sim 10-25 \mathrm{~km}$ in length). Occasionally, a cell bow echo (CBE) developed from an isolated cell without any apparent outside interaction 
[16-18]. Studies on bow echoes outside the US in different environments are still limited, with only a few exceptions (e.g., [19-24]).

The present study deals with the study of the organized MCSs such as "Bow Echoes" with the help of ground based DWR and Radiosonde observations over the Indian region. The observations from these sensors are supplemented by National Centers for Environmental Prediction (NCEP) reanalyzed data and ground based rainfall data from $3 \mathrm{~B} 42$ (V6) data product of Tropical Rainfall Measuring Mission (TRMM) over the study area. In this study the evolution and life cycles of two different bow echo events on October 24 and 26-27, 2006, are considered.

\section{System Description and Data Used}

For the present study, the observations from DWR at Satish Dhawan Space Centre (SDSC), Sriharikota $\left(13.66^{\circ} \mathrm{N}\right.$ and $\left.80.23^{\circ} \mathrm{E}\right)$, India, are utilized. This DWR operates in S-band (2.8 GHz frequency $/ 10 \mathrm{~cm}$ wavelength) and is normally configured as a fixed station. DWR consists of a high power coherent transmitter, a pencil beam antenna with $1^{\circ}$ width, and very low side lobe levels. It is steerable in azimuth and elevation. The digital signal processor extracts the three essential base products, namely, reflectivity $(Z)$, radial velocity $(V)$, and spectral width $(\sigma)$ of hydrometeors from the log/linear channels of the receiver. The Radiosonde observations are taken from the University of Wyoming website. The wind data are taken from the NCEP reanalyzed data and ground based rainfall data are from 3B42 (V6) data product of TRMM over the study area.

\section{Case Study}

3.1. Life Cycle Study of Cell Bow Echo (CBE) with the Help of Ground Based DWR: A Case Study on October 24, 2006. The life cycle of the cell bow echo (CBE) is studied with the reflectivity and radial velocity data from the DWR. The PPI plots of reflectivity at different instances of time are shown in Figures 1(a)-1(e). This particular CBE evolved from two small isolated cells with reflectivity $\geq 40 \mathrm{dBZ}$ as shown by the PPI plot of reflectivity at $0.5^{\circ}$ at 12:47 UTC (Figure 1(a)). These cells moved (South-West direction) towards each other form the radar site (Figure 1(b)). At 13:09 UTC a CBE formed (Figure 1(c)) that persisted till 13:13 UTC. The next scan at 13:30 UTC showed the decaying of the CBE and then lost its bow shape as can be observed from low reflectivity from the DWR observation. The decaying stage of the CBE did not show the comma shaped echo but instead it ended up with some unorganized shape as can be seen (Figure 1(e)). This particular CBE was short lived (life time $<1 \mathrm{~h}$ ). Figures 2(a) and 2(b) show the vertical cross section of the reflectivity and radial velocity, respectively, through the $\mathrm{CBE}$, along azimuth number 223. The vertical structure consists of one single matured cell with $20 \mathrm{dBZ}$ echoes reaching up to $10 \mathrm{~km}$ while $40 \mathrm{dBZ}$ echoes extended uniformly from ground to $\sim 5 \mathrm{~km}$ height. The interesting point to be noted here is the echo overhang of reflectivity $>30 \mathrm{dBZ}$, which is a prominent feature of the early matured stage of $\mathrm{CBE}$ [18], observed rear of the convective core (Figure 2(a)). The radial velocity was quite high with value $>-15 \mathrm{~m} / \mathrm{s}$ towards the radar at the upper height (about 6 to $11 \mathrm{~km}$ ) and the lower height is predominant with velocity away from the radar (about 5 to $15 \mathrm{~m} / \mathrm{s}$ ) (Figure 2(b)). This pair of opposite direction of velocity might be responsible for the bow or bulge shape of the radar echo [18]. Below the echo overhang negative radial velocity was noticed that might be the indicative of updraft in that region and positive radial velocity at upper level near $40 \mathrm{~km}$ suggests the up-shear tilt of the updraft [18].

3.2. Life Cycle Study of Squall Line Bow Echo (SLBE) with the Help of Ground Based DWR: A Case Study on October $26 / 27,2006$. The life cycle of a squall line bow echo of trailing stratiform (TS) type on October 26 and 27, 2006, is studied with the help of DWR data. Figures 3(a)-3(f) show the evolution and propagation of the squall line. This particular squall line bow echo has its origin over ocean and moved towards the radar site and decayed thereafter as can be observed from the low reflectivity values. The MCS evolved at 23:03:09 UTC on October 26, 2006, over ocean (Figure 3(a)). After the evolution it starts moving towards the radar site. The radar reflectivity pattern for this squall line showed that it was TS type squall lines as can be seen from the figure where stratiform region is trailing the convective region [25]. The length of the squall line was $\sim 200 \mathrm{~km}$. A closer look at the Figure 3(b) showed two squall lines: one oriented in WestSouth direction and another on East-South direction. These two squall lines joined together and emerged as a single squall line with a prominent bow shape of its leading convective line (Figure 3(c)). This bow shape of the leading convective line continues till 07:30:16 UTC (Figure 3(f)). Thereafter it decayed with the formation of another squall line in the eastern direction.

To see how the system varied in terms of reflectivity, as a whole, with time, the Contour Frequency Altitude Diagram (CFAD) has been constructed for four hours when the system was inside the $200 \mathrm{~km}$ radius from the radar site (Figures 4(a), 4(b), 4(c), and 4(d)). The bin size considered in this study is $4 \mathrm{dBZ}$; that is, while plotting frequency of the reflectivity the interval considered is $4 \mathrm{dBZ}$. Figure 4 (a) shows the CFAD of reflectivity at 4:32:40 UTC. It can clearly be noticed that the echo tops are reaching more than $12 \mathrm{~km}$ height. Without the unavailability of the higher elevation data CFAD becomes flat at about $12 \mathrm{~km}$. The CFAD at 5:37:13 UTC (Figure 4(b)) shows existence of higher percentage of 30 and $40 \mathrm{dBZ}$ echoes compared to previous hour while the percentage of reflectivity $<30 \mathrm{dBZ}$ was more or less similar up to the height of $5 \mathrm{~km}$. By the next hour the drastic reduction was observed in the percentage of lower reflectivity $\sim 10-14 \mathrm{dBZ}$ at the height of 2.5 to $5 \mathrm{~km}$ (Figures $4(\mathrm{c})$ and $4(\mathrm{~d})$ ). But at the same time percentage of higher reflectivity increases and by the time $07: 32: 16$ with $1 \%$ of $30 \mathrm{dBZ}$ echo reached up to the height of $10 \mathrm{~km}$ and $40 \mathrm{dBZ}$ echoes reached up to the height of $\sim 8 \mathrm{~km}$ (Figure $4(\mathrm{~d})$ ). These CFADs show the continuous growth of the MCS while moving towards the radar site.

Figures 5(a) and 5(b) show the vertical cross section of reflectivity and corresponding radial velocity, respectively, along the azimuth 174 through the squall line at 4:32:40 


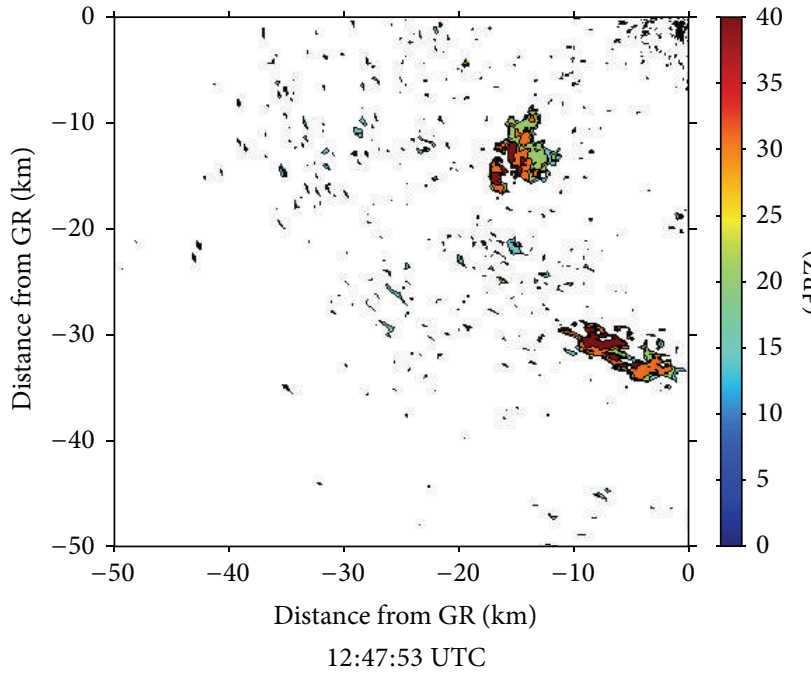

(a)

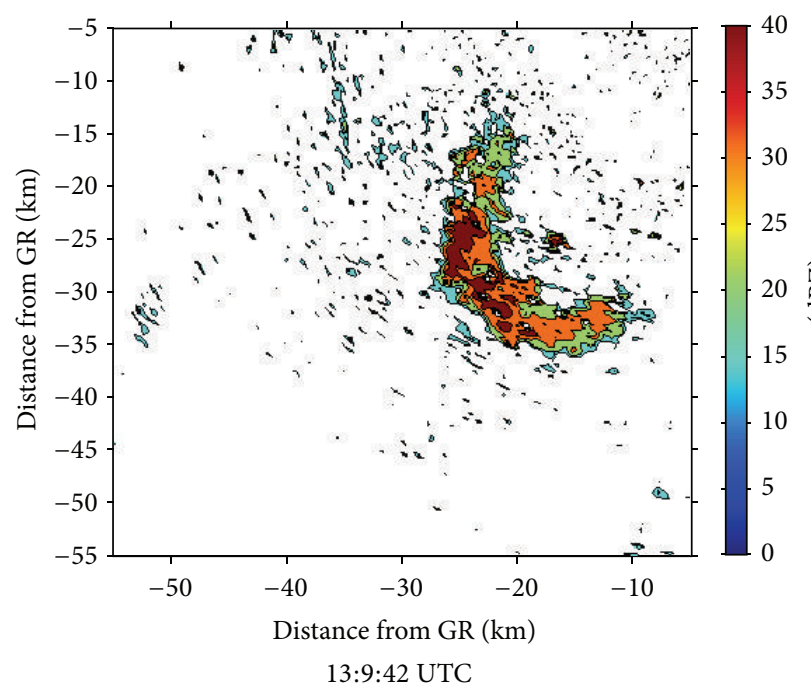

(c)

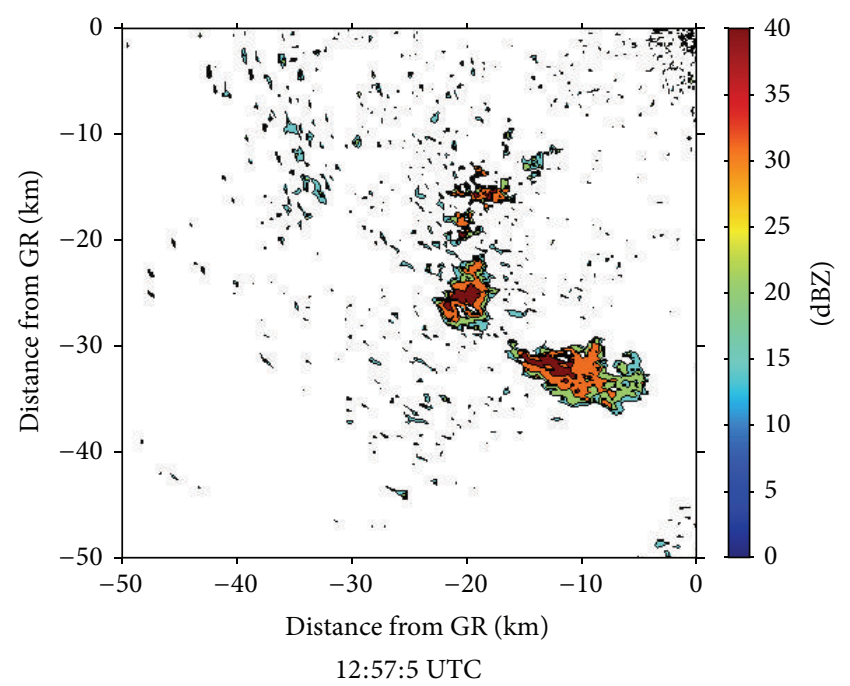

(b)

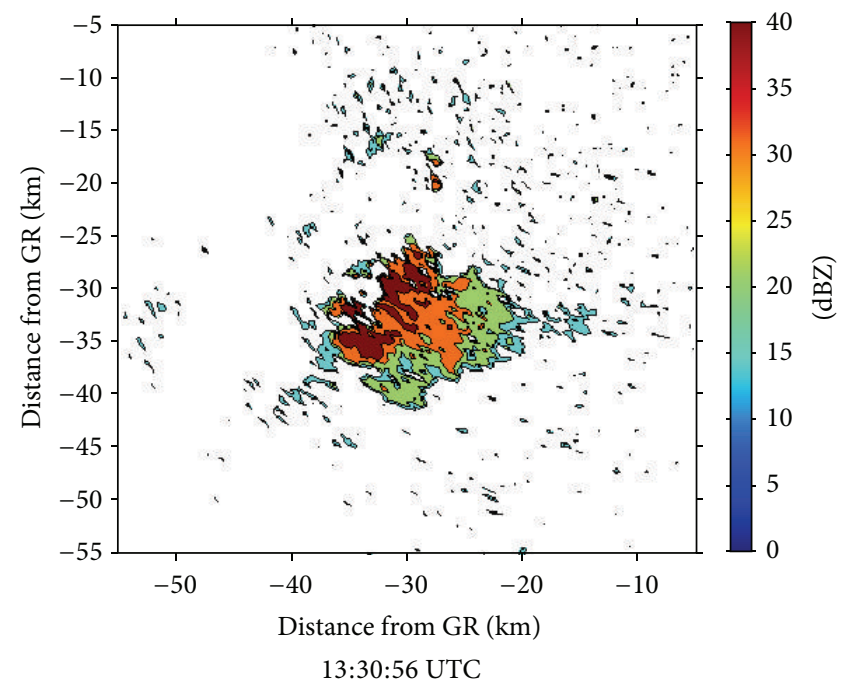

(d)

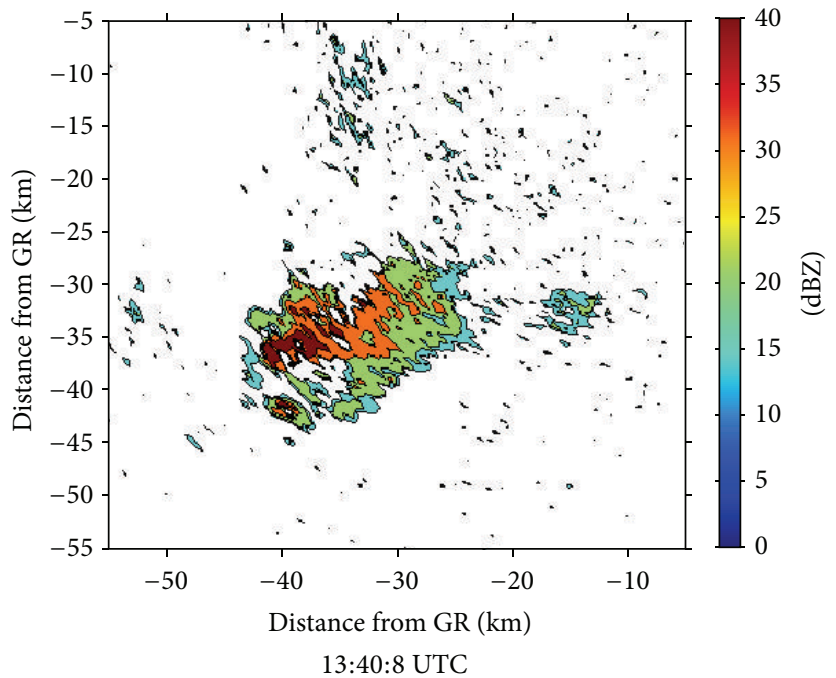

(e)

FIGURE 1: Evolution and decay of cell bow echo (CBE) as observed by DWR on October 24, 2006. 


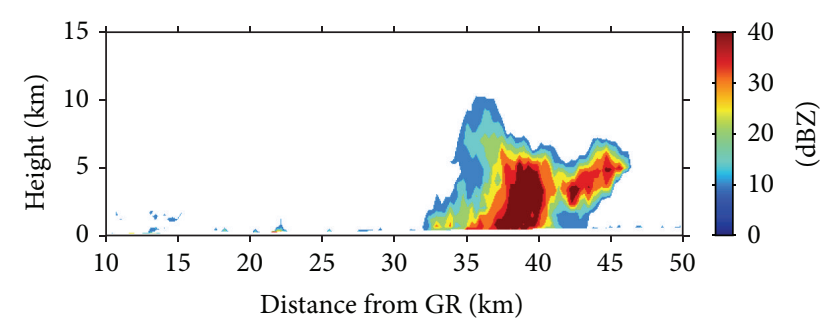

(a)

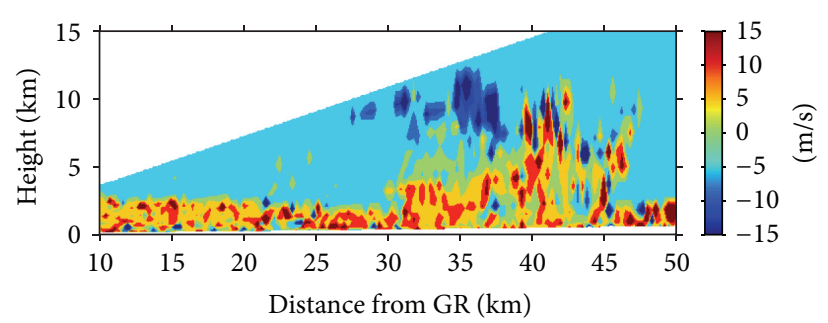

(b)

FIGURE 2: Vertical cross section (a) reflectivity (dBZ) and (b) radial velocity (m/s) of the CBE along azimuth number 223.

UTC. Figure 5(a) shows the three regions of the squall line: convective, transition, and stratiform which are very much distinct in the height profiles of reflectivity. The stratiform region is identified with the help of bright band at around $5.0 \mathrm{~km}$ and for convective region reflectivity height is found to be $>6.0 \mathrm{~km}$. The transition region is in between the convective and stratiform regimes. A distinct rear inflow jet (RIJ) can be noticed with radial velocity of value more than $-10 \mathrm{~m} / \mathrm{s}$ (Figure 5(b)). A moderately strong front-to-rear (FTR) velocity can also be seen in the opposite direction of RIJ. The RIJ and FTR were found to be the strongest over the transition region. The RIJ started from $\sim 6 \mathrm{~km}$ height and entered to the base of the convective cell. DWR observations were started from $0.5^{\circ}$ elevation. Thus due to the curvature effect, lower height data was not available. The persistence bow shape of the squall line may be related to the rear inflow jet (RIJ). The wind pattern on October 27 at 00 UTC, as observed from NCEP data, shows a line of confluence at $850 \mathrm{mb}$ where there are two low level jets (LLJ) at $850 \mathrm{mb}$ level: one from the South-West direction and the other one from a easterly jet occurred (Figure 6). Strong convergence of wind occurred from the two jets at that level that supplied enough moister to make it a long-lived system [26]. The squall line bow echo hits the Chennai sounding station $\left(13.00^{\circ} \mathrm{N}\right.$, $80.18^{\circ} \mathrm{E}$ ) at 5:37:13 UTC. Sounding observation taken at 00 UTC, before the arrival of the squall line bow echoes, showed an unstable atmosphere with being mostly moist at all levels (Figure $7(\mathrm{a})$ ). The large CAPE value $(1714 \mathrm{~J} / \mathrm{kg}$ ) and low CIN value $(0 \mathrm{~J} / \mathrm{kg})$ designated the approaching squall line bow echo. The low level wind shear $(0-3 \mathrm{~km})$ was found to be $\sim 15 \mathrm{~m} / \mathrm{s}$. A temperature inversion occurs with colder air below and warmer air above (Figure 7(a)). While investigating the sounding observation in the post-squall, Zipser [27] observed an onion or diamond shape structure of the temperature and dew point curves. Sounding at Madras station at 12 UTC after the passage of the squall line shows similar structure in the sounding (Figure 7(b)).

The spatial distribution of total rainfall accumulation between 18 UTC on October 26 and 06 UTC October 27, 2006, as observed from the combined instrument rain calibration algorithm (3B-42, version 6) is shown in (Figure 8). The grid resolution is $0.25 \times 0.25$ degrees. This is an optimal combination of 2B-31 (TRMM), 2A-12 (TRMM), SSMI, AMSR, and AMSU precipitation estimates to adjust IR estimates from geostationary IR observations. The bow shape of the squall line can also be depicted from the rain structure. Rain accumulation of greater than $130 \mathrm{~mm}$ can be seen at around $12^{\circ} \mathrm{N}$ and $80^{\circ} \mathrm{E}$.

\section{Results and Discussion}

Life cycles of CBE and SLBE are studied with the DWR observations. Vertical pattern of reflectivity and radial velocity showed tilting of the system as observed by Jorgensen et al. 1997 for a tropical squall line bow echo. Prominent $30 \mathrm{dBZ}$ echo overhang was observed rear of the convective core. This CBE had different characteristics compared to the CBE studied by Lee et al. [16, 17]. The CBE studied here formed from two isolated cells in contrast to the single cell evolution of CBE which Lee et al. 1992 has studied. It is noteworthy, however, to mention that this is a preliminary study compared to the more detailed and complete study of Lee et al. [16, 17]. The kinematics of the squall line bow echoes are studied with the help of radial velocity from DWR. The role of RIJ and FTR for the formation of bow shape of the squall line has been shown. The RIJ and FTR flow are most intriguing feature of squall line bow echo [9]. The RIJ is a layer of low thetae air that enters the MCS from the rear below the trailing anvil cloud of the stratiform region and descends towards the leading convective line. Theta-e (or equivalent potential temperature) is the temperature a parcel of air would have if it were lifted until it became saturated, all water vapor was condensed out, and it was returned adiabatically (i.e., without transfer of heat or mass) to a pressure of 1000 millibars. The RIJ plays a crucial role in supplying potentially cool and dry midlevel air to aid in the production of convective and system-scale downdrafts. Weisman [28] in his study showed descending RIJ flow is often associated with a decaying system, whereby the gust-front lifting is not strong or deep enough to regenerate new convective cells and the mesoscale circulation slowly weakens. The FTR flow is an opposing current of system relative flow which flows above the RIJ. The ascending front-to-rear flow in the stratiform region is important in both qualitative and quantitative study since its horizontal component spreads the ice particle out into the region of stratiform region and helps in forming the bright band and its vertical component supplies the moisture for the growth by vapor deposition of the ice particle. Strong inflow cases were observed both from Radiosonde as well as from Doppler weather radar (DWR) [9]. On the contrary Knupp et al. [29] showed locally evolved stratiform region for a small vigorous MCS in low-shear environment but not through 


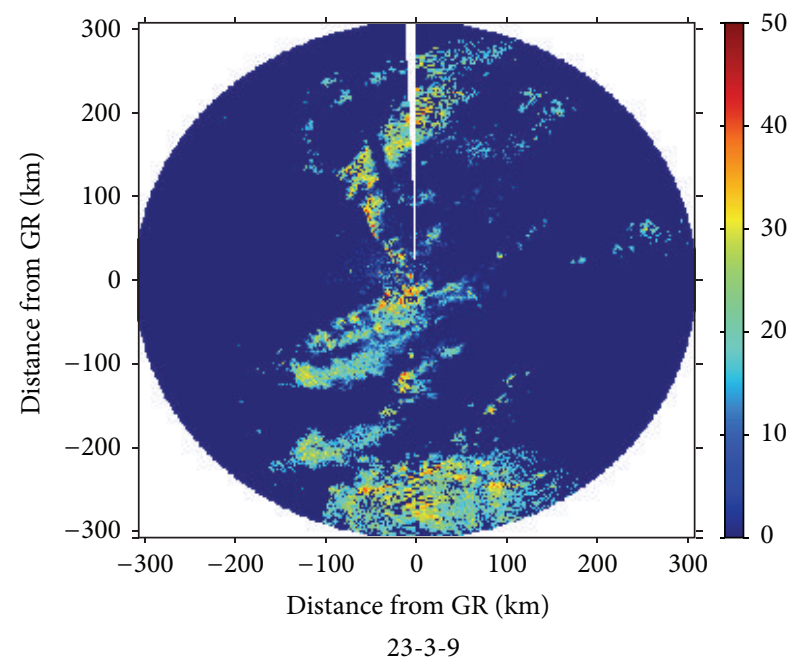

(a)

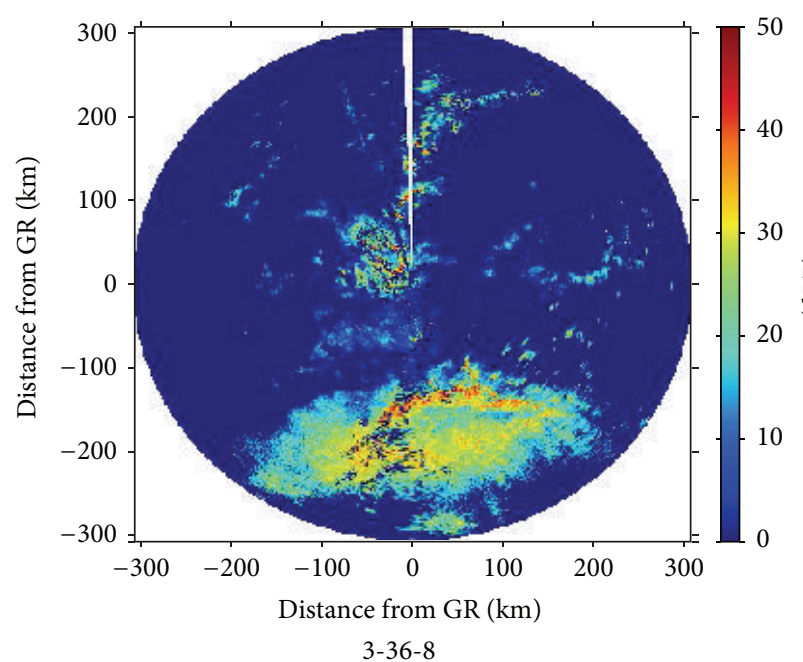

(c)

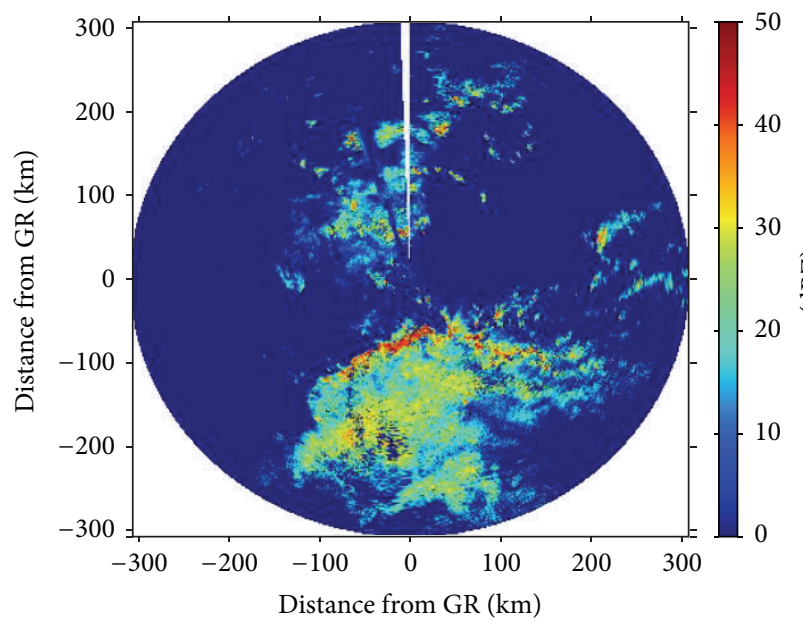

5-37-17

(e)

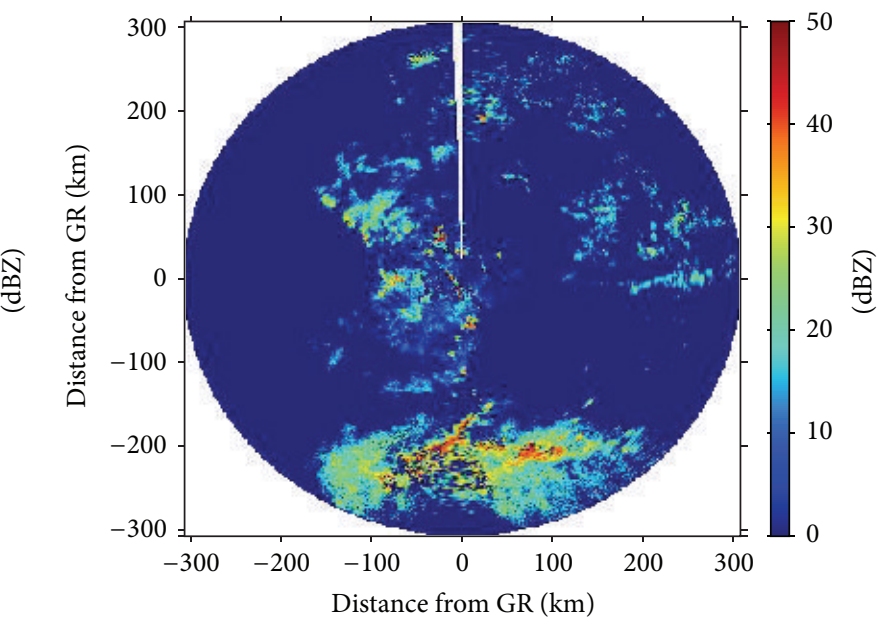

$1-15-51$

(b)

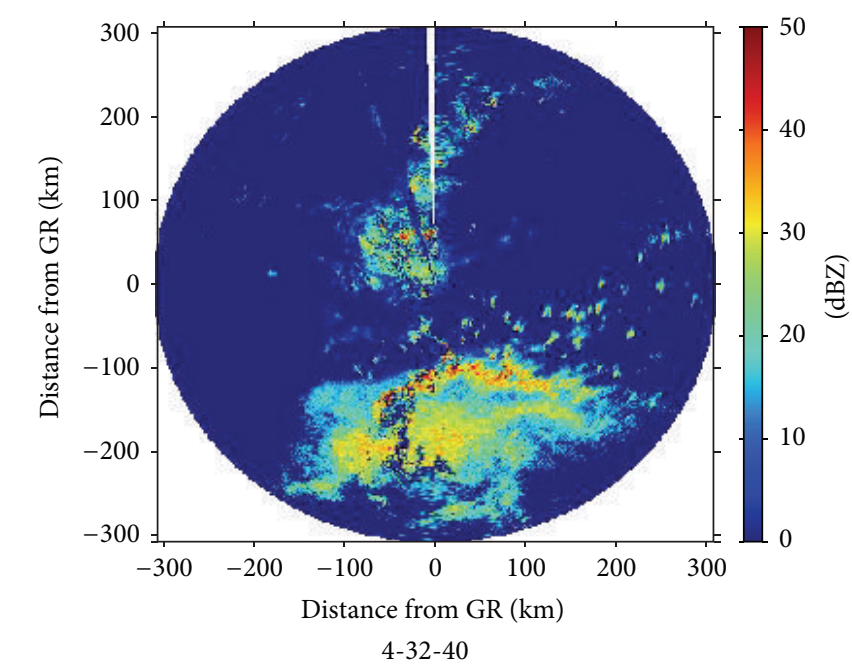

(d)

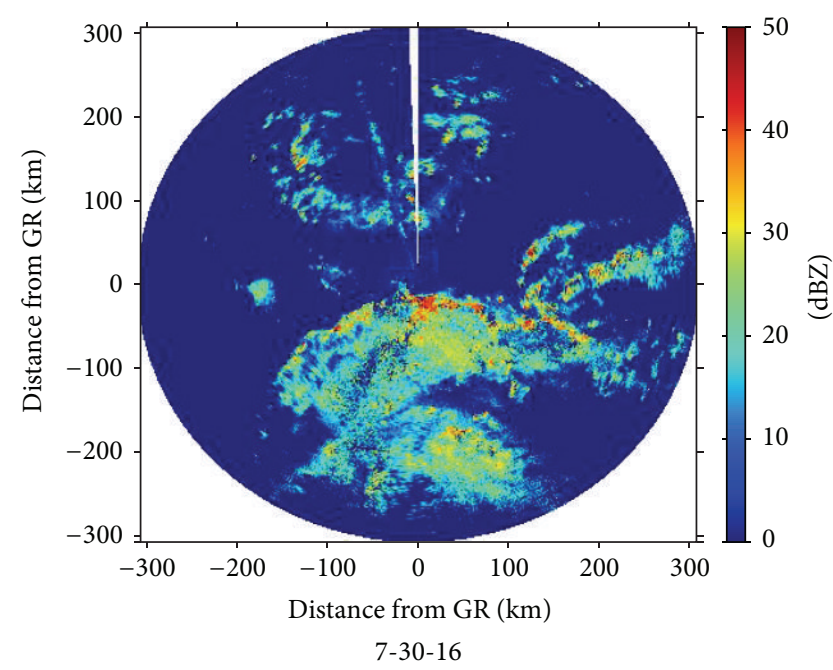

(f)

FIGURE 3: Squall line movement tracked by DWR on October 26 and 27, 2006. 

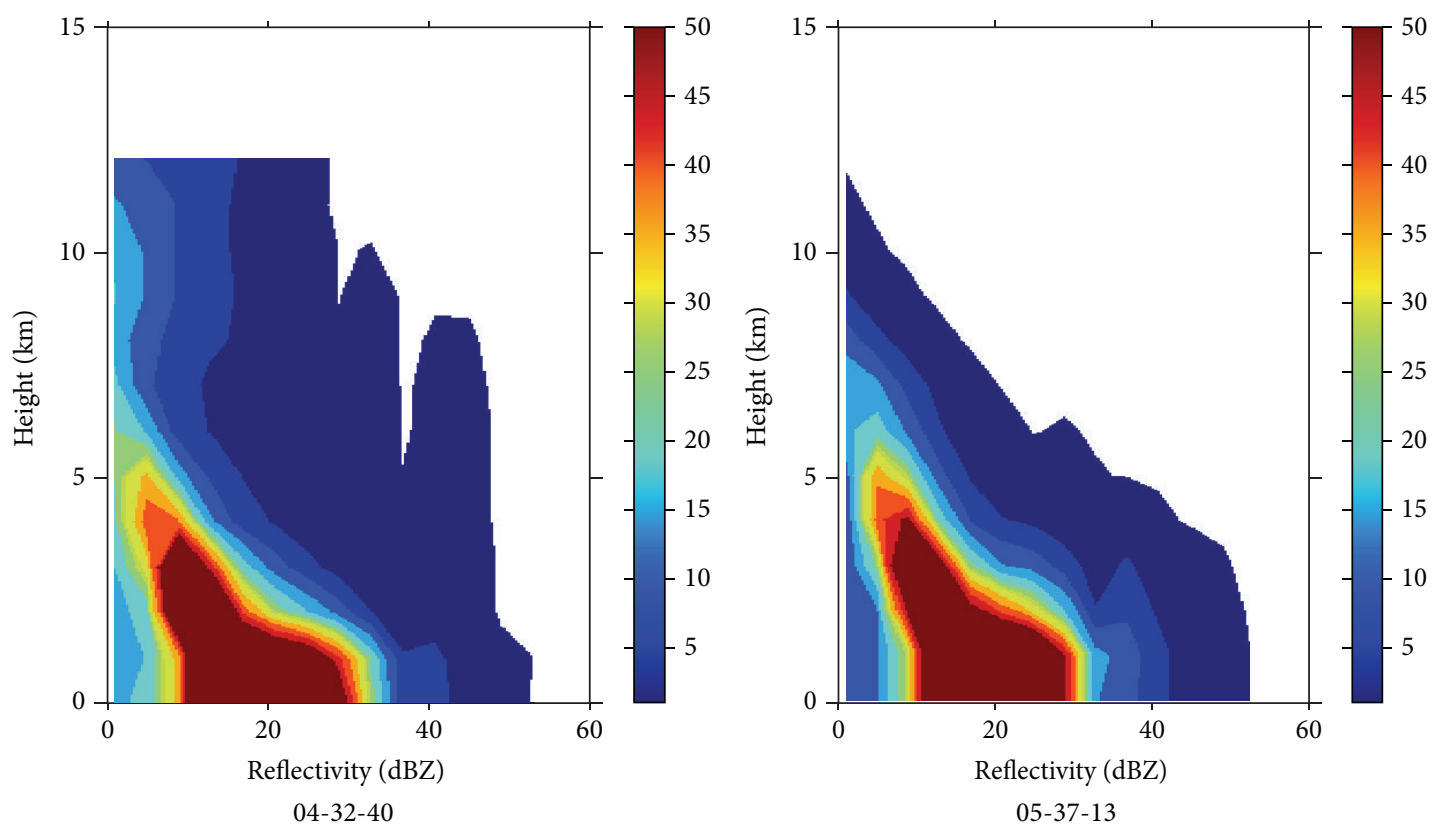

(a)

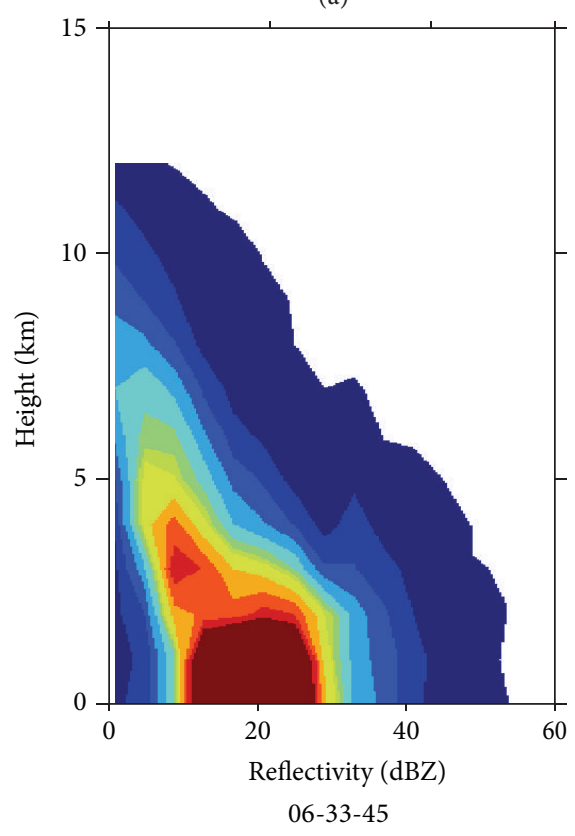

(c)

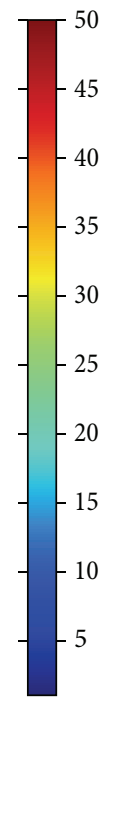

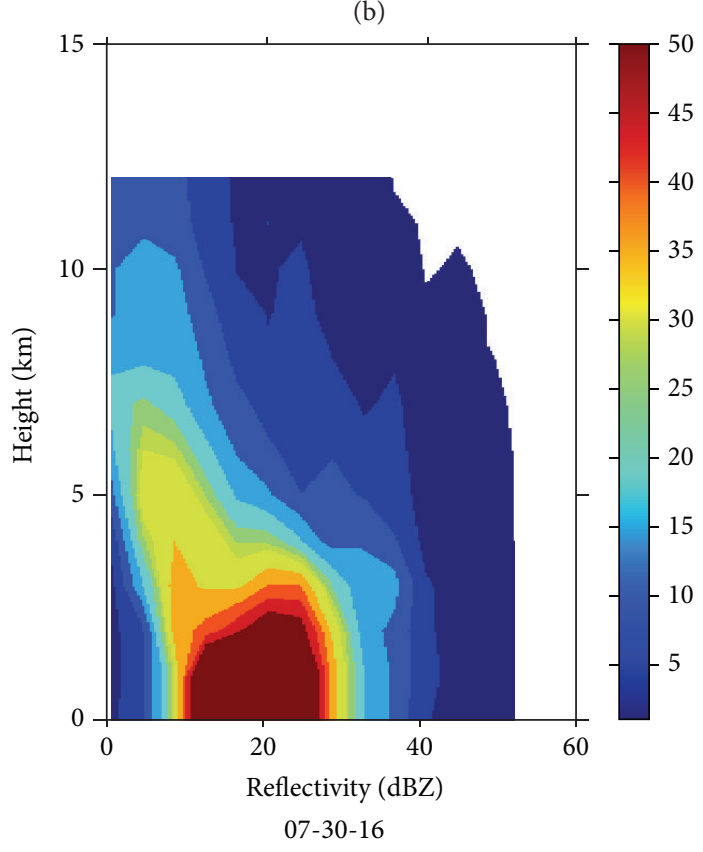

(d)

FIGURE 4: CFADs of reflectivity of the squall line bow echo on October 27, 2006. Bin size (reflectivity interval) is $4 \mathrm{dBZ}$. Colour bar values indicate the percentage of occurrence of reflectivity.

the rearward advection of ice particle from the leading convective line. Their analysis of radar reflectivity revealed in situ formation of stratiform region in the presence of weak mesoscale updraft as decaying convective cores collapsed.

\section{Conclusion}

From the case study of the CBE and SLBE it is found that bow echoes are associated with severe weather and high rain over the ground. The developed systems are associated with very high reflectivity up to higher heights ( $40 \mathrm{dBZ}$ echo heights are found up to $6 \mathrm{~km}$ ) and weak echo region. Weak echo regions are the region of strong updrafts without hydrometeor [30]. The favorable synoptic condition for the organized MCS over peninsular India is mainly the strong southerly wind (from Bay of Bengal), strong vertical velocity, and large CAPE values. Bow echo are associated with high amount of ground rainfall. The cell bow echo is found to be short lived $(<1 \mathrm{hr})$ 


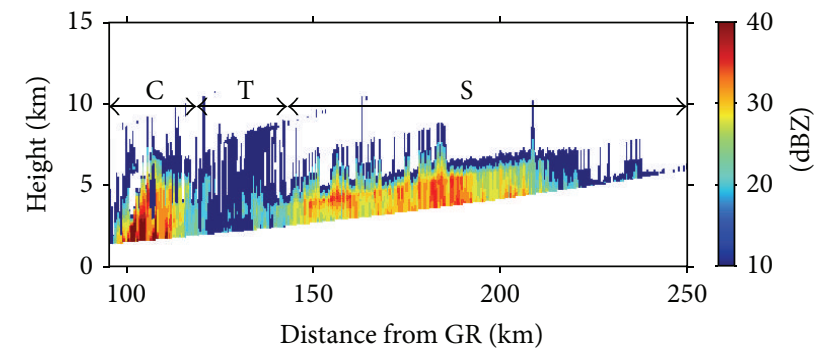

(a)

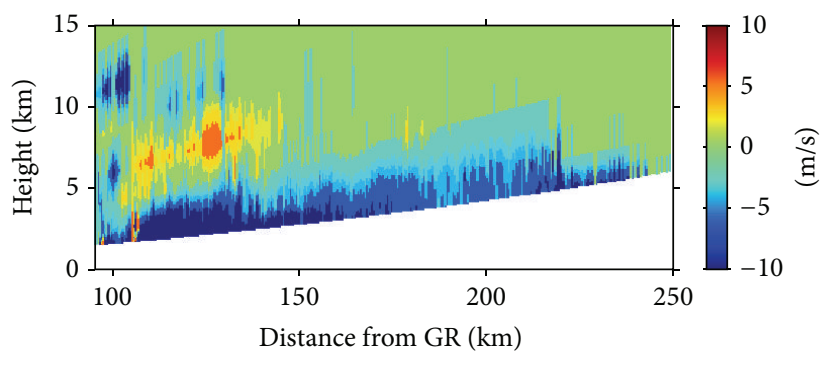

(b)

FIGURE 5: (a) Vertical cross section of reflectivity showing the convective (C), transition (T), and stratiform (S) region and (b) corresponding rear inflow jet for October 27, 2006, along azimuth number 174 .

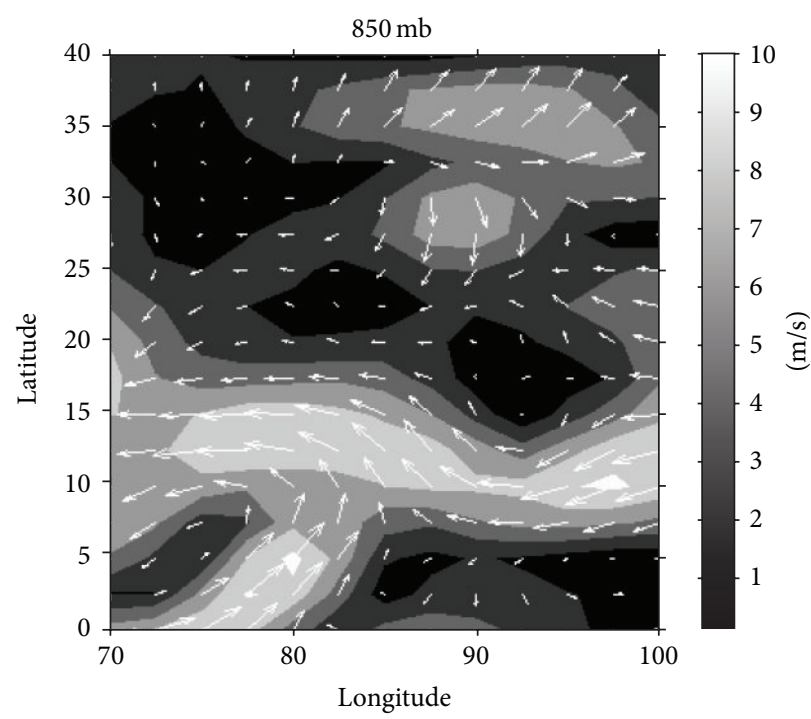

FIGURE 6: Wind pattern during the squall line bow echo event on October 27, 2006, as observed from NCEP data at 00 UTC at 850 mb.

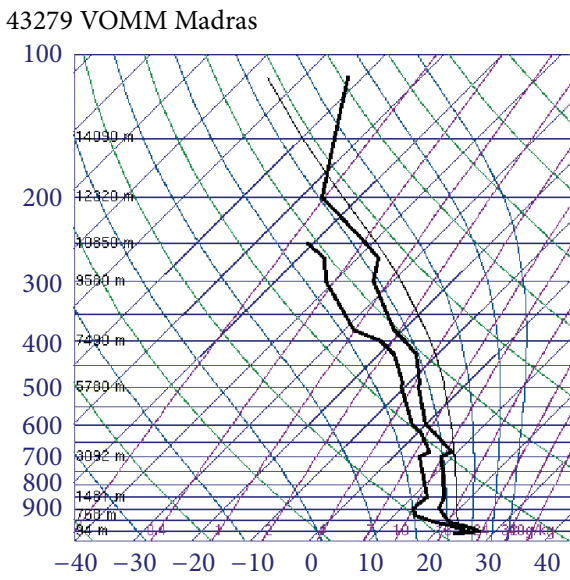

00Z 27 Oct 2006

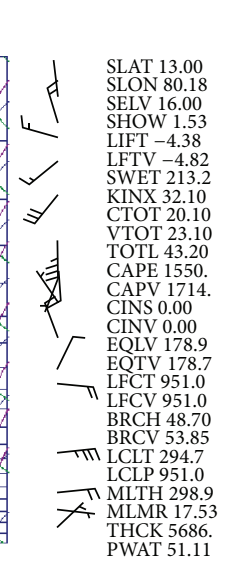

University of Wyoming

(a)

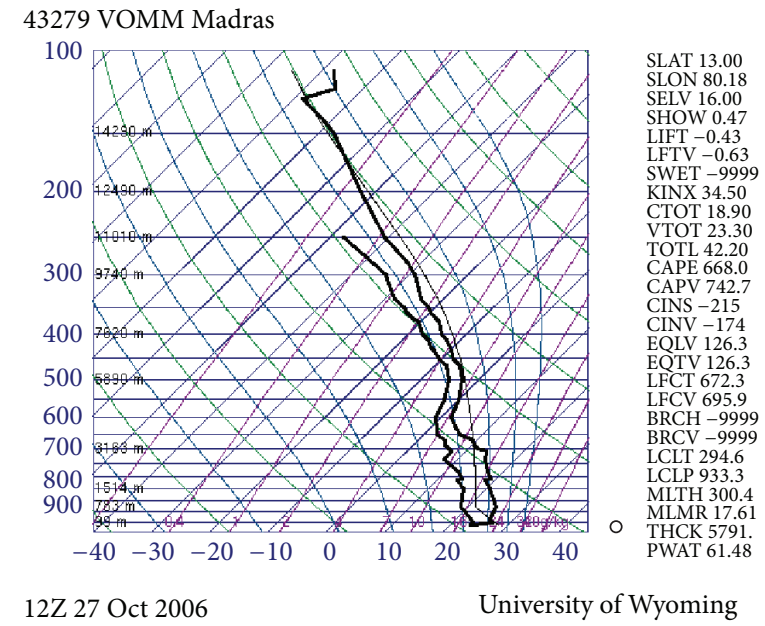

(b)

FIGURE 7: Atmospheric sounding (a) before and (b) after the passage of the squall line over the sounding site. 


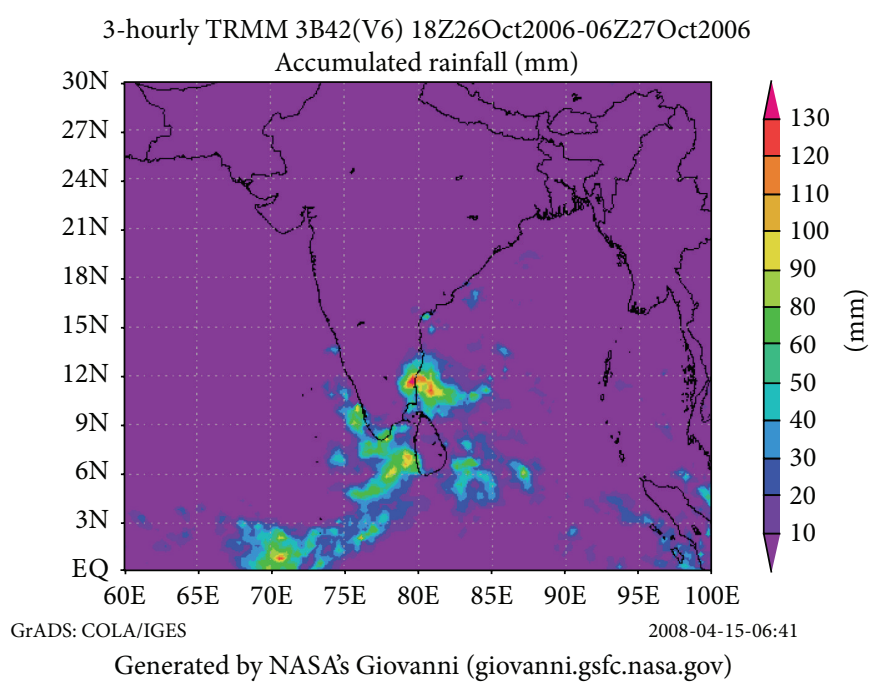

FIGURE 8: Spatial distribution of rainfall accumulation between 18 UT on October 26 and 06 UT on October 27, 2006, as observed from the 3B42 (V6) data product.

and squall line bow echoes are found to be long lived ( $6 \mathrm{hrs})$. The bow echoes are found to be associated with strong RIJ and FTR as observed by radial velocity measurements from DWR.

The life cycle study of CBE over the Indian region shows that it was formed from two isolated cells and was short lived. On the other hand the SLBE in this region formed in an environment of less low level wind shear as compared to the strong wind shear in case of midlatitude bow echoes. These are the main findings of this preliminary case study about the CBE and SLBE over the Indian region. This study is probably the first of its kind over this region. Further study will be concentrated on their occurrences and climatological aspects.

\section{Conflict of Interests}

The authors declare that there is no conflict of interests regarding the publication of this paper.

\section{Acknowledgment}

The present work is supported by the Indian Space Research Organization (ISRO), Department of Space, under the RESPOND Project (10/4/524). Authors are thankful to Shri G. Viswanathan, formerly Director, ISRAD, Bangalore, India, for useful discussion and advice regarding the DWR data and his encouragement to carry out this study. Thanks also go to IMD for providing the DWR data. The authors acknowledge the University of Wyoming, NCEP, and TSDIS for the data utilized in this study. Authors from Kohima Science College are thankful to the Principal for providing the necessary facilities to carry out the present work.

\section{References}

[1] R. J. Doviak and D. S. Zrnić, Doppler Radar and Weather Observation, Academic Press, San Diego, Calif, USA, 1993.
[2] M. A. LeMone, E. J. Zipser, and S. B. Trier, "The role of environmental shear and thermodynamic conditions in determining the structure and evolution of mesoscale convective systems during TOGA COARE," Journal of the Atmospheric Sciences, vol. 55, no. 23, pp. 3493-3518, 1998.

[3] J.-J. Wang, "Evolution and structure of the mesoscale convection and its environment: a case study during the early onset of the southeast Asian summer monsoon," Monthly Weather Review, vol. 132, no. 5, pp. 1104-1120, 2004.

[4] J.-J. Wang and L. D. Carey, "The development and structure of an oceanic squall-line system during the South China Sea Monsoon Experiment," Monthly Weather Review, vol. 133, no. 6, pp. 1544-1561, 2005.

[5] J.-J. Wang, X. Li, and L. D. Carey, "Evolution, structure, cloud microphysical, and surface rainfall processes of monsoon convection during the South China Sea monsoon experiment," Journal of the Atmospheric Sciences, vol. 64, no. 2, pp. 360-380, 2007.

[6] T. Rigo and M. C. Llasat, "Radar analysis of the life cycle of Mesoscale Convective Systems during the 10 June 2000 event," Natural Hazards and Earth System Science, vol. 5, no. 6, pp. 959970, 2005.

[7] R. A. Houze Jr., B. F. Smull, and P. Dodge, "Mesoscale organization of springtime rainstorms in Oklahoma," Monthly Weather Review, vol. 118, no. 3, pp. 613-654, 1990.

[8] M. D. Parker and R. H. Johnson, "Organizational modes of midlatitude mesoscale convective systems," Monthly Weather Review, vol. 128, no. 10, pp. 3413-3436, 2000.

[9] B. F. Smull and R. A. Houze Jr., "Rear inflow in squall lines with trailing stratiform precipitation," Monthly Weather Review, vol. 115, no. 12, pp. 2869-2889, 1987.

[10] M. I. Biggerstaff and R. A. Houze Jr., "Kinematics and microphysics of the transition zone of the 10-11 June 1985 squall line," Journal of the Atmospheric Sciences, vol. 50, no. 18, pp. 3091-3110, 1993.

[11] R. A. Houze Jr., "Structure and dynamics of a tropical squall-line system," Monthly Weather Review, vol. 105, no. 12, pp. 1540-1567, 1977. 
[12] C. A. Demott and S. A. Rutledge, "The vertical structure of TOGA COARE convection. Part I: radar echo distributions," Journal of the Atmospheric Sciences, vol. 55, no. 17, pp. 2730-2747, 1998.

[13] T. T. Fujita, Manual of Downburst Identification for Project Nimrod, Satellite and Mesometeoroiogy Research Paper No. 156, Department of Geophysical Sciences, University of Chicago, 1978.

[14] B. A. Klimowsky, M. J. Bunkers, M. R. Hjelmfelt, and J. N. Covert, "Severe convective windstorms over the northern high plains of United States," Weather and Forecasting, vol. 18, pp. 502-519, 2003.

[15] B. A. Klimowsky, M. R. Hjelmfelt, and M. J. Bunkers, "Radar observations of the early evolution of bow echoes," Weather \& Forecasting, vol. 19, pp. 727-734, 2004.

[16] W.-C. Lee, R. E. Carbone, and R. M. Wakimoto, “The evolution and structure of a "bow-echo-microburst' event. Part I: the microburst," Monthly Weather Review, vol. 120, no. 10, pp. 21882210, 1992.

[17] W.-C. Lee, R. E. Carbone, and R. M. Wakimoto, "The evolution and structure of a "bow-echo-microburst" event. Part II: the bow echo," Monthly Weather Review, vol. 120, no. 10, pp. 22112225, 1992.

[18] K. R. Knupp, "Structure and evolution of a long-lived, microburst-producing storm," Monthly Weather Review, vol. 124 , no. 12 , pp. 2785-2806, 1996.

[19] D. P. Jorgensen, M. A. LeMone, and S. B. Trier, "Structure and evolution of the 22 February 1993 TOGA COARE squall line: aircraft observations of precipitation, circulation, and surface energy fluxes," Journal of the Atmospheric Sciences, vol. 54, no. 15, pp. 1961-1985, 1997.

[20] S. Businger, T. Birchard Jr., K. Kodama, P. A. Jendrowski, and J.-J. Wang, "A bow echo and severe weather associated with a kona low in Hawaii," Weather and Forecasting, vol. 13, no. 3, pp. 576-591, 1998.

[21] W. Schmid, H.-H. Schiesser, M. Furger, and M. Jenni, "The origin of severe winds in a tornadic bow-echo storm over northern Switzerland," Monthly Weather Review, vol. 128, no. 1, pp. 192-207, 2000.

[22] R. W. Przybylinski and D. M. DeCaire, "Radar signatures associated with the derecho. One type of mesoscale convective system," in Proceedings of the 14th Conference On Severe Local Storms, pp. 228-231, American Meteor Society, Indianapolis, Ind, USA, 1985.

[23] M. L. Weisman, "Bow echoes: a tribute to T. T. Futija," Bulletin of the American Meteorological Society, vol. 82, pp. 97-116, 2001.

[24] G. T.-J. Chen, C.-C. Wang, and H.-C. Chou, "Case study of a bow echo near Taiwan during wintertime," Journal of the Meteorological Society of Japan, vol. 85, no. 3, pp. 233-253, 2007.

[25] B. F. Smull and R. A. Houze Jr., "A midlatitude squall line with a trailing region of stratiform rain: radar and satellite observations," Monthly Weather Review, vol. 113, no. 1, pp. 117133, 1985.

[26] M. L. Weisman, "The genesis of severe, long-lived bow echoes," Journal of the Atmospheric Sciences, vol. 50, no. 4, pp. 645-670, 1993.

[27] E. J. Zipser, "Mesoscale and convective-scale downdrafts as distinct components of squall-line structure," Monthly Weather Review, vol. 105, pp. 1568-1589, 1977.

[28] M. L. Weisman, "The role of convectively generated rear-inflow jets in the evolution of long-lived mesoconvective systems,"
Journal of the Atmospheric Sciences, vol. 49, no. 19, pp. 1826-1847, 1992.

[29] K. R. Knupp, B. Geerts, and S. J. Goodman, "Analysis of a small, vigorous mesoscale convective system in a low-shear environment. Part I: formation, radar echo structure, and lightning behavior," Monthly Weather Review, vol. 126, no. 7, pp. 1812-1858, 1998.

[30] D. J. Musil, A. J. Heymsfield, and P. L. Smith, "Microphysical characteristics of a well-developed weak echo region in a High Plains supercell thunderstorm," Journal of Climate \& Applied Meteorology, vol. 25, no. 7, pp. 1037-1051, 1986. 

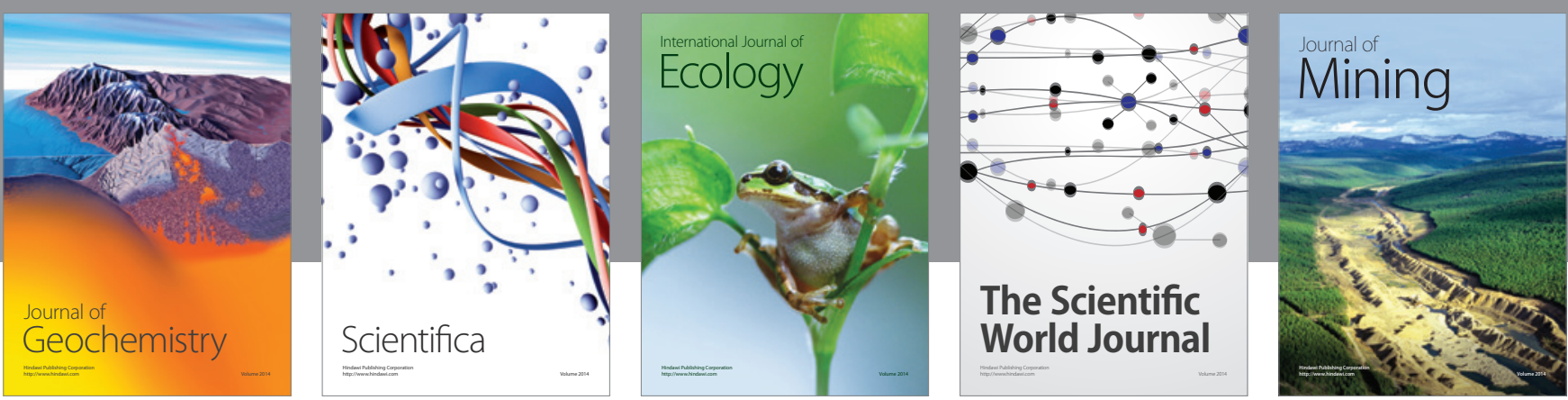

The Scientific World Journal
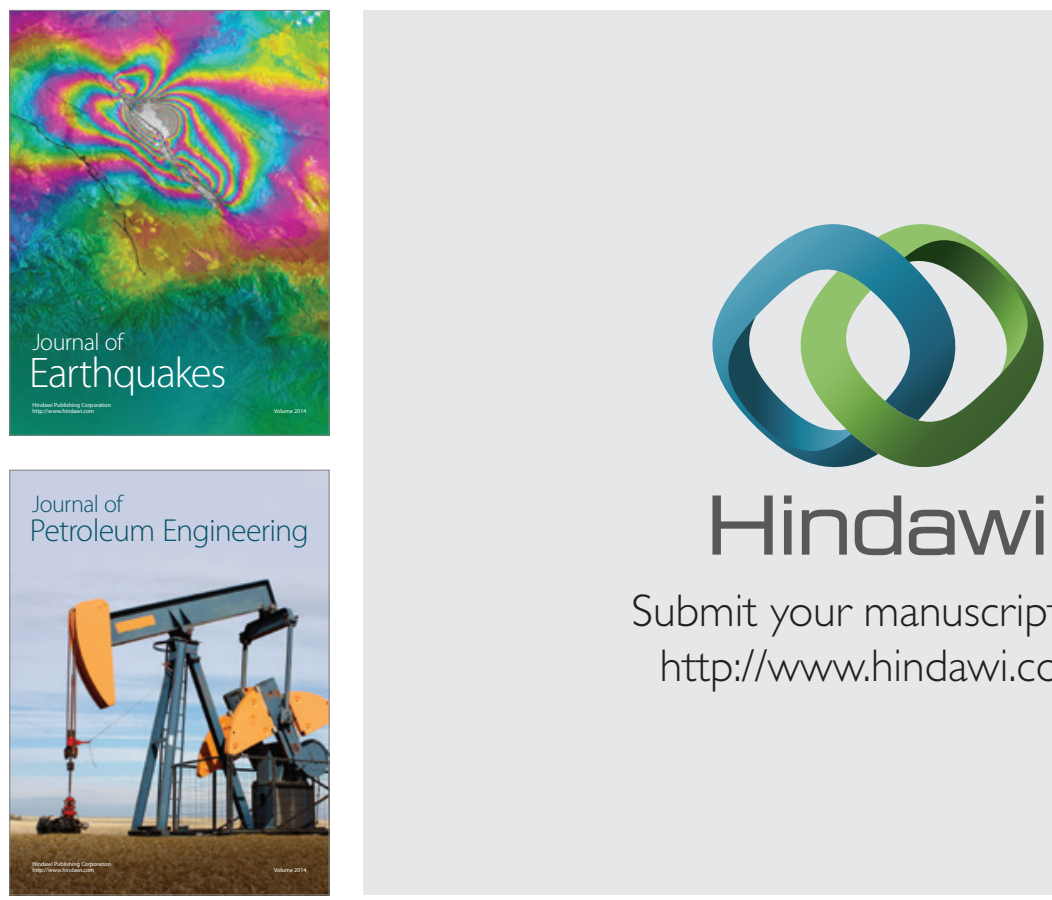

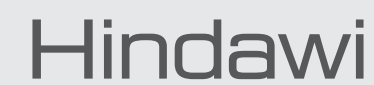

Submit your manuscripts at

http://www.hindawi.com
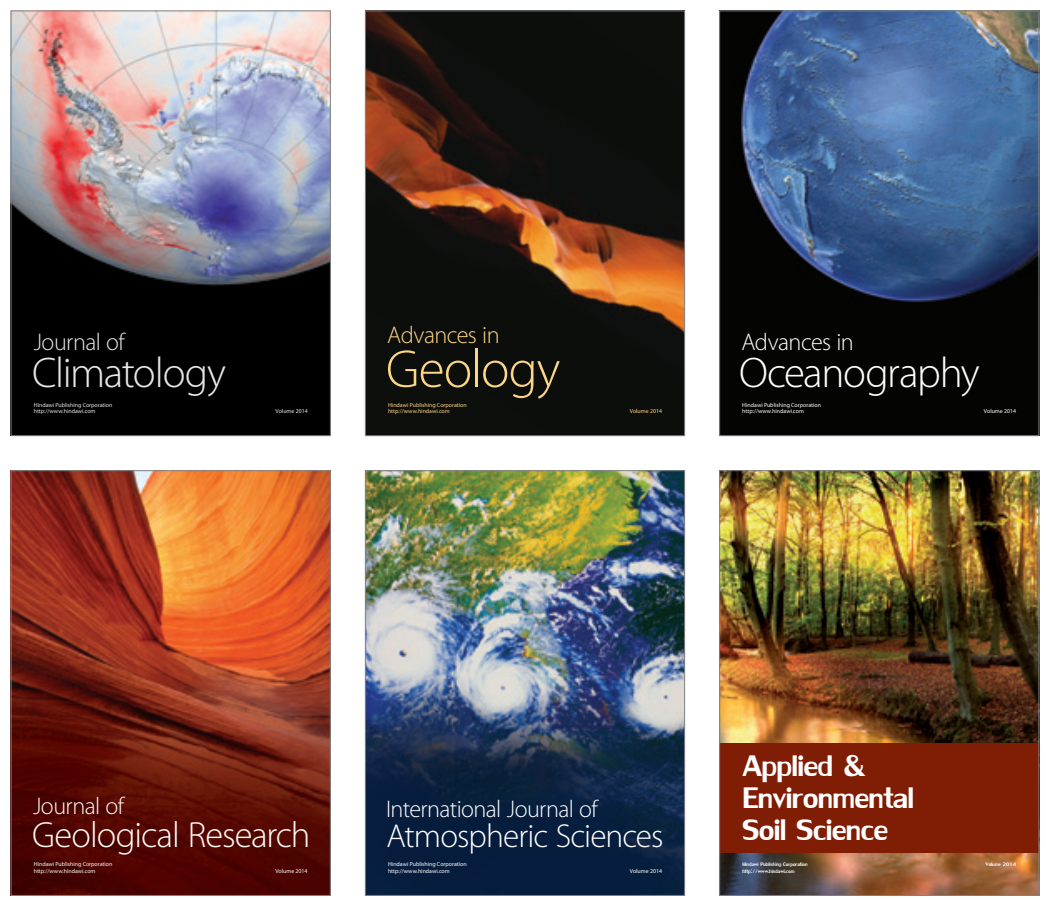
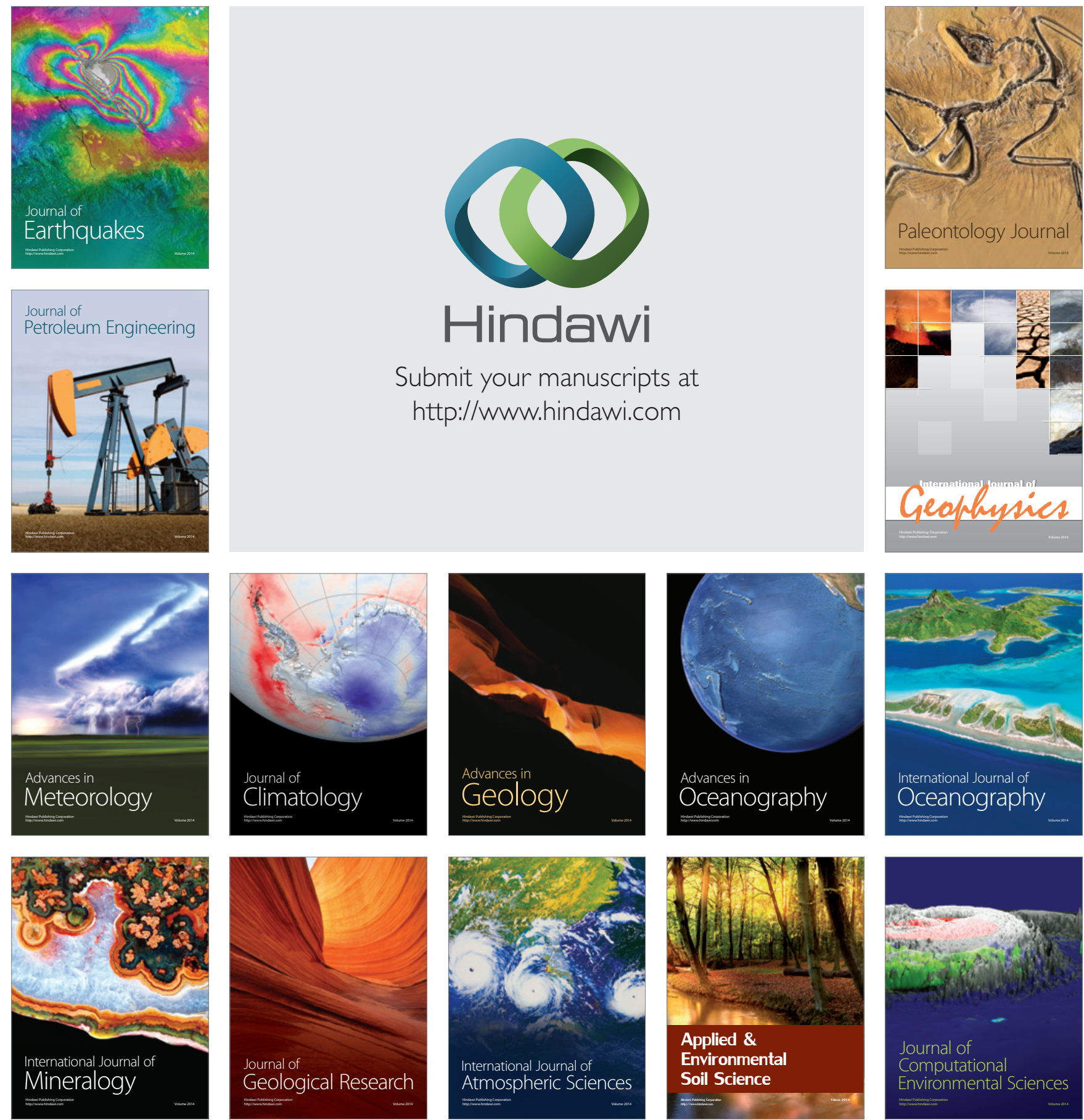